\title{
Comparison of Glutathione Peroxidase Activity in Erythrocytes and Certain Tissues between Voles and Mice
}

\author{
Toshiro ARAI, Toshihiko WATANABE, Shigeru HAMADA, and Moriyuki SUGAWARA \\ Division of Veterinary Biochemistry, Nippon Veterinary and Animal Science University, \\ 1-7-1 Kyonan-cho, Musashino-shi, Tokyo 180, Japan
}

(Received 22 July 1992/Accepted 29 January 1993)

\begin{abstract}
Glutathione peroxidase (GSH-Px) activities in erythrocytes and certain tissues were investigated in herbivorous voles and $\mathrm{C} 57 \mathrm{BL} / 6 \mathrm{~J}$ mice. In both voles and mice, GSH-Px activities in liver, kidney and erythrocyte were higher than those of the other tissues, such as adipose tissue, pancreas and skeletal muscle. Voles showed lower GSH-Px activities in liver, kidney, erythrocyte and brain compared with mice. - KEY WORDS : glutathione peroxidase, mouse, vole
\end{abstract}

\section{八タネズミとマウスの赤血球および組織における グルタチオンペルオキシターゼ活性の比較}

新井敏郎・渡辺利彦・浜田茂・菅原盛幸

日本獣医畜産大学獣医生理化学教室

グルタチオンペルオキターゼ(GSH - Px, EC 1.11.1.9)は過酸化水素によるへモグロビンの酸化を 防ぐ酵素として, ウシ赤血球より精製されて以来多く の研究がなされてきた[10]。本酵素は分子内にセレン を含む同一のサブユニット 4 個から成る 4 量体で，七 レン欠乏飼料で動物を飼育するとその活性が低下する [6]。また，動物種間で本酵素活性は著しい差のある ことが知られている $[5,11,16]$ 。

今回, 草食性家畜のモデル動物として飼育, 繁殖さ れているハタネズミならびにC $57 \mathrm{BL} / 6 \mathrm{~J}$ マウスの赤 血球および諸組織の GSH-Px 活性について測定し, 検討した。

当研究室で飼育繁殖している 7 ～8 月齢のハンガ リー産ハタネズミMicrotus arvalis Pallas（雌 4, 雄
4 , 計 8 頭) と, 対照として $57 \mathrm{BL} / 6 \mathrm{~J}$ マウス（雌 3 , 雄 3 , 計 6 頭) を実験に用いた。八タネズミは草 食性動物用ペレットZC（オリエンタル酵母社）と一 イキューブを, C57BL/6J マウスは固型飼料 $\mathrm{CMF}$ （オリエンタル酵母社）を自由捸食させ，水は自由飲 水とした。動物は室温 $22 \sim 26^{\circ} \mathrm{C}$, 湿度 $40 \sim 60 \%, 14$ 時 間照明 $(7: 00-21 ： 00) の$ 条件下で飼育した。動物は 10：00-12:00の間に頸部切断法によりと殺, 頸静脈 から採血した。全血 $0.5 \mathrm{~m} \ell$ に $1 \mathrm{~m} \ell$ の隇菌生理食塩水 を加え $100 \mathrm{~g}, 5$ 分間遠心分離する操作を2回繰り返し 赤血球を洗浄した。その後 $9 \mathrm{~m} \ell$ の $10 \mathrm{mM}$ Tris- $\mathrm{HCl}$ 緩 衝液 $(\mathrm{pH} 7.4)$ を加之, 溶血させ ${ }^{\circ} \mathrm{C}, 6,000 \mathrm{~g}, 20$ 分間 遠心分離して得た上清を赤血球酵素抽出液とした [1]。一方, 肝荿, 心茂, 堅珹については, と殺後, 
Table 1. Glutathione peroxidase (GSH-Px) activity in erythrocytes and tissues of voles or mice

\begin{tabular}{lcc}
\hline & \multicolumn{2}{c}{$\begin{array}{c}\text { Specific activity } \\
\text { (nmol/min/mg protein) }\end{array}$} \\
\cline { 2 - 3 } & Voles (8) & Mice (6) \\
\hline Erythrocyte & $31.2 \pm 3.5^{\mathrm{a}}$ & $58.6 \pm 7.4$ \\
Liver & $169.0 \pm 30.2^{\mathrm{a}}$ & $435.0 \pm 40.4$ \\
Kidney & $97.8 \pm 13.7^{\mathrm{a}}$ & $288.4 \pm 32.0$ \\
Brain & $44.8 \pm 6.8^{\mathrm{a}}$ & $60.3 \pm 9.2$ \\
Heart & $52.1 \pm 8.8$ & $60.3 \pm 8.6$ \\
Pancreas & $32.3 \pm 7.3$ & $33.6 \pm 5.0$ \\
Skeletal muscle & $30.5 \pm 5.6$ & $38.0 \pm 6.5$ \\
Adipose tissue & $142.0 \pm 18.3$ & $172.6 \pm 24.6$ \\
\hline
\end{tabular}

Values are presented as mean \pm S.D. The numbers in parentheses indicate the number of animals studied. $\mathrm{a}:$ significantly different $(\mathrm{P}<0.01)$ from the value of mice

直ちに開腹し， $1 \mathrm{mM}$ EDTA， $5 \mathrm{mM} \mathrm{2-メルカプトエ}$ タノールを含む50mM Tris- $\mathrm{HCl}$ 緩衝液, $\mathrm{pH} 7.5$ [9] で灌流した後，摘出した。骨格筋 (腓腹筋), 膵藏, 脳，脂肪組織は摘出後，上記瘋衝液中で洗浄した。各 組織の重量を測定し,その 4 倍量の上記緩衝液を加 え，ガラスホモゲナイザーによりホモゲナイズした。 $4^{\circ} \mathrm{C}, 15,000 \mathrm{~g}, 30$ 分間遠心分離後, 上清を取りさら に $4^{\circ} \mathrm{C} ， 100,000 \mathrm{~g}, 30$ 分間遠心分離して得た上清を組 織酵素抽出液として測定に用いた。

$\mathrm{GSH}-\mathrm{Px}$ 活性は,リン酸楥衝液に GSH と酵素抽 出液を加え，クルタチオンレタクターゼーNADPH 系を共役させ, $340 \mathrm{~nm}$ の吸光度の減少で測定した。 すなわち，反応混液 $\{$ 全量 $2.5 \mathrm{~m} \ell ； 50 \mathrm{mM}$ リン酸緩 衝液, $\mathrm{pH} 7.0,0.16 \mathrm{mM}$ NADPH, $1 \mathrm{mM}$ アジ化ナト リウム, $0.4 \mathrm{mM}$ EDTA, $1 \mathrm{mM} \mathrm{GSH}, 2 \mu \mathrm{g} / \mathrm{m} \ell$ ク ルタチオンレタクターゼ（醥母製，オリエンタル醉母 社) \}に, 䤃素抽出液 $0.02 \mathrm{~m} \ell$ を加之, さらに最終濃

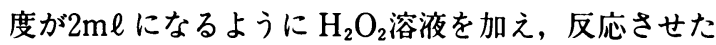
[12]。酵素活性は，1分間に1mgの蛋白質が酸化した NADPH のモル数で表した。酵素抽出液中の蛋白量 は Bradfordの方法[2]により測定した。

ハ夕ネズミと C57BL 系マウスの赤血球および組織 中の GSH-Px 活性を Table 1に示した。各 GSH-Px 活性について，ハ夕ネズミ，マウスともに雌雄差は認 められなかった。各々の組織間で GSH-Px 活性を比 較してみると, 八タネズミ, マウスともに肝醎，督 㗪，脂肪組織が高い值を示した。またハタネズミの

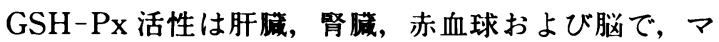
ウスのそれに比較して有意に低い值を示した。
ハ夕ネズミ，マウスで認められた組織間での GSH$\mathrm{Px}$ 活性の違いは他の動物でも認められる $[13,14,16]$ 。骨格筋や勝硪では特にセレン欠乏時に白 筋症, ジストロフィーあるいは膵倳線維症といった過 酸化脂質の蓄積が原因と考えられる障害の発生が報告 されている $[3,8,14]$ 。また，最近ストレプトゾシンや アロキサン投与による榶尿病の誘発因子のひとつに過 酸化水素の生成增加が推測されている $[15]$ 。骨格筋や 膵䂝の GSH-Px 活性は他の践器に比較して低い傾向 にあり,これらの障害の発生機構と関連する可能性が ある。

一方，八タネズミはマウスに比へてて各組織において GSH-Px 活性が低い傾向が認められた。ウシ，ヒッ ジ，ウマなど草食動物やニワトリでは，一般に肝や督 での GSH-Px 活性がマウス, ラット等に比べ著しく 低いことが知られている $[7,16]$ 。さらに GSH-Px 活 性は組織中のセレン濃度と関連することが明らかにな っており，ラットではセレン濃度の高い肝や堅は高い GSH-Px 活性を示す [4]。また, 飼料に含まれるセレ ン化合物の種類によって利用率が異なることが知られ ている[3]。

近年, ウシやヒッジにおいて，白筋症などセレン欠 乏症の発生が問題となっているが，これらの発生には 単にセレン含量の量的な不足だけでなく，七レン化合 物の種類, ビタミン $\mathrm{E}$ との相互作用など種々の要因が 関連している $[3,13,14]$ 。動物においてセレン久乏症 の発生機構を調へるためには, 飼料中のセレン含量を 変えたり, 含まれるセレン化合物の種類を変えて，そ の利用率を比較することが必要であるが，ウシやヒッ ジのような大動物を使っての実験は経済的に極めて困 難である。八タネズミはウシやヒッジと同様 GSH$\mathrm{Px}$ 活性がマウス等に比へ低い傾向を有しており，小 型で取扱いやすいことからウシやヒツジにおけるセレ ン欠乏症の発生機序について詳細な検討を行うための 有用なモデル動物となると考えられる。

\section{要的}

草食性ハ夕ネズミと C57BL/6J マウスの赤血球お よび諸組織におけるグルタオンペルオキシターゼ (GSH-Px) 活性を比較検討した。ハ夕ネズミ, マ

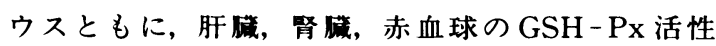
が, 脂肪組織, 膵硪, 骨格筋に比較して高かった。ま

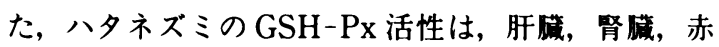


血球および脳で，マウスに比べ低い値を示した。

\section{文献}

[1] Beutler, E. (1969). J. Clin. Invest., 48, 1957-1966.

[2] Bradford, M. M. (1976). Anal. Biochem., 12, 248254.

[3] Cantor, A. H., Langevin, M. L., Noguchi, T., and Scott, M. L. (1975). J. Nutr. 105, 106-111.

[4] Chow, C. K. and Jeng, J. (1981) In Selenium in Biology and Medicine. pp. 477-482, Spallholz, J. E., Martin, J. L. and Ganther, H. E. (eds.), Avi Publishing Company, Westpoint.

[5] Duan, Y.-J., Kumura, S., Fiszer-Szafarz, B., Szafarz, D., and Yagi, K. (1988). J. Biol. Chem., 263, 19003-19008.

[6] Hafeman, D. G., Sunde, R. A., and Hoekstra, W. G. (1974). J. Nutr., 104, 580-587.
[ 7 ] Harvey, J. W. and Kaneko, J. J. (1975) . Comp. Biochem. Physiol., 52B, 507-510

[8] Jacobsson, S. O., Lidman, S., and Linderg, P. (1970). Acta Vet. Scand., 11, 324-326.

[9] Liu, M. S. and Sharma, C. (198). Am. J. Physiol., 240, R10-R15.

[10] Mills, G. C. (1959). J. Biol. Chem., 234, 502-506.

［11］宮崎 茂・元井媵子 (1992). 家音生化研報, 28，11-20.

[12] Nakamura, W., Hosoda, S., and Hayashi, K. (1974). Biochim. Biophys. Acta., 358, 251-261.

[13] Noguchi, T., Cantor, A. H., and Scott, M. L. (1973).J. Nutr., 103, 1502-1511.

[14] Paynter, D, I., Anderson, J. W., and MacDonald, J. W. (1979). Aust. J. Agric. Res., 30, 703-709.

[15] Takasu, N., Komiya, I., Asawa, T., Nagasawa, Y., and Yamada, T. (1991). Diabetes., 40, 11411145.

[16] Tappel, M. E., Chaudiere, J., and Tappel, A. L. (1982). Comp. Biochem. Physiol., 73B, 945-949. 